\title{
Modelling forest resilience in Hindu Kush Himalaya using geoinformation
}

\author{
M D Behera ${ }^{1, *}$, M S R Murthy ${ }^{2}, \mathrm{P} \mathrm{Das}^{1}$ and E Sharma ${ }^{2}$ \\ ${ }^{1}$ Centre for Oceans, Rivers, Atmosphere and Land Sciences (CORAL), Indian Institute of Technology Kharagpur, \\ Khargpur 721302, India. \\ ${ }^{2}$ International Centre for Integrated Mountain Development (ICIMOD), GPO Box 3226, Kathmandu, Nepal. \\ *Corresponding author.e-mail: mdbehera@coral.iitkgp.ernet.in
}

MS received 20 March 2017; revised 20 December 2017; accepted 7 January 2018; published online 18 August 2018

Resilience is the capacity of an ecosystem to absorb disturbance and undergo change while maintaining its essential structure, functions, identity and feedbacks. The forests of the Hindu Kush Himalayan (HKH) region are vulnerable to both natural and anthropogenic changes, and the forest land conversion and degradation. Using satellite-derived tree canopy cover percent data and precipitation as the explaining variable, we studied the forest cover resilience in a geospatial framework employing the logistic regression and polynomial equation fitting. Out of the 4.3 million $\mathrm{km}^{2}$ geographical areas, $873,650 \mathrm{~km}^{2}(20.20 \%)$ was under the forest in 2000 and experienced loss of $11,250 \mathrm{~km}^{2}$ during $2000-2010$. We could model the forest cover and treeless areas fairly than the scrub and grassland owing to the variation in precipitation pattern. The majority of the forest cover $(59.3 \%)$ has been estimated to have less resilience owing to the receipt of $<1650 \mathrm{~mm}$ of total annual precipitation, whereas only $375 \mathrm{~km}^{2}$ forest area could change to scrub that shows the least resilience. About $94.4 \%$ of treeless areas were estimated to be stable, while only $1 \%\left(25,200 \mathrm{~km}^{2}\right)$ area could accommodate the grassland. The resilient forest areas estimated and observed, owing to the mapping and modelling protocols used in this study, shall be useful in conservation planning in the HKH region.

Keywords. Remote sensing; forest cover change; logistic regression; precipitation; tree canopy cover.

\section{Introduction}

Ecosystems are subjected to spatio-temporal disturbances of both natural and anthropogenic nature. The conservation and management practices to mitigate such disturbances or to eliminate the impact of long-term large disturbances without perceiving the slower and rare ones could be a failure (Dale et al. 1998). Thus, the biodiversity conservation could be a failure without incorporating slow change processes such as climate regime shift that may alter the ecosystem functions. The capacity of an ecosystem to absorb such disturbances while undergoing changes maintaining its essential structures, functions, identity and feedbacks is termed as ecological resilience (Holling 1973; Walker et al. 2004). The resilience of a system can be estimated by studying the

Supplementary material pertaining to this article is available on the Journal of Earth System Science website (http://www. ias.ac.in/Journals/Journal_of_Earth_System_Science). 
magnitude of disturbances it can absorb without undergoing significant transformational changes. In forests, the resilience is defined as the capacity to recover from severe disturbances, such as fire, logging, climate change, etc., to its original state and beyond which it experiences undesired shifts to the available alternative stable states. This definition of resilience therefore assumes the existence of alternative states in a forest ecosystem (e.g., forest to scrubland or from scrubland to grassland) and is primarily concerned with (i) how the changes in the structure of an ecosystem can alter its behaviour and (ii) how a given state persists over time (Holling 1973; Gunderson 2000). The resilience theory also states that the complex systems such as forests do not simply tend towards an equilibrium condition, but rather cycle dynamically based on the tension between forces that are selected for efficiency (Gunderson and Holling 2002).

Climate has major influence that defines the plant functioning as photosynthesis, respiration and other processes as well as forest structures, diversity and their growth rates. Forests have been adapting to the fast-changing climate and in course, abandoning the existing locations and migrating to newer locations leading to a shift in latitudinal and altitudinal gradients. Generally, most well-developed forests, especially primary old forests, are both resilient and resistant to changes. Drier forests are more vulnerable to climate change as they are more prone to fire and droughts (Anderson-Teixeira et al. 2013). Apart from the quantitative change, the forests are changing qualitatively by its density and connectivity (Roy et al. 2013; Behera et al. 2014). The forests are also vulnerable to anthropogenic alterations such as forest land conversion and degradation, fragmentation due to the construction of rail-road, urban encroachment, agriculture, mining, etc. (Chitale and Behera 2014). The loss of ecosystem resilience due to the reduction in the size of the basin of attraction is also been linked with the diversity loss as the more diverse system has the benefit of high complementarity gains (Folke et al. 2004). Thus, it also necessitates the biodiversity conservation to maintain the resilient ecosystem that ensures sustainable flow of ecosystem goods and services to the society.

The theory of alternative stable states in a forest ecosystem suggests that the regime shift among various forest formations of grass-shrub, savannas and woody plants is dependent on the mutual interaction and utility of competition to dry season, precipitation, fire events, etc., with varied intensity and frequency (Folke et al. 2004). Bucini and Hanan (2007), Hirota et al. (2011) and Staver et al. (2011) have also studied the alternative stable states among forest, savanna and treeless states in reference to precipitation at continental and intercontinental scales in Africa, southeast Asia, Australia and South America. They observed that the tree canopy cover percent (TCC\%) gradually increased with the precipitation following a double hysteresis curve corresponding to the resilient zones of three dominant forest types (Hirota et al. 2011). This implied that the forest cover that belonged to the wetter zones is more resilient and has one end transition probability towards savanna that received lesser precipitation. However, the savannas are resilient to moderate amount of precipitation, and have upper and lower end transition probabilities to forest and treeless states, with increase and decrease in precipitation, respectively. Treeless areas belonging to drier areas are more resilient, and showed change proneness towards the savanna with the increase in precipitation. Following this distribution pattern of TCC $\%$ w.r.t. the precipitation, Hirota et al. (2011) fitted the sigmoid curve and used the logistic regression to derive the resilience of each forest cover type, whereas Bucini and Hanan (2007) added the growing season length, soil properties, fire frequency, cultivation intensity, human population, cattle density into account. Staver et al. (2011) added the fire frequency, dry season length and soil properties to estimate the forest cover resilience while using a generalised additive model.

The forests of the Hindu Kush Himalayan (HKH) region are experiencing change of varied magnitudes due to the climate and anthropogenic disturbances, and different forest management policies practiced by different countries sharing the region (Das et al. 2017). The varied spatial distribution of precipitation and temperature makes the HKH region a unique mountainous landscape, where the southern aspect receives higher solar illumination and sub-tropical monsoon precipitation. On the other hand, the varied topography and high altitude mountains restrict the monsoon precipitation in the northern aspects, which are characterised by dry and cold waves in the Tibetan plateau. Moreover, the western part of this landscape is characterised by drier and warmer climate. This varied climate influenced the forest cover distribution pattern, restricting up to $5500 \mathrm{~m}$ along the elevation gradient (Singh and Singh 1987). 
With the global climate change, the $\mathrm{HKH}$ region is also experiencing a temperature rise of $0.2^{\circ} \mathrm{C}$ per decade since 1960 (Chen et al. 2013). The rates of winter and autumn warming have been significantly faster than those of spring and summer in this region. Southern Asia $\left(5-50^{\circ} \mathrm{N} ; 64-100^{\circ} \mathrm{E}\right)$ comprising the $\mathrm{HKH}$ region observed an increasing trend of $0.9^{\circ} \mathrm{C}$ per decade in mean annual temperature and $0.12 \mathrm{~mm} /$ decade in precipitation in the past century (Harris et al. 2014). The mean annual temperature is expected to rise by $2.6-5.2^{\circ} \mathrm{C}$ by 2100 under two scenarios [Intergovernmental Panel on Climate Change (IPCC) A2 and B1; Chen et al. 2013]. Since 1960, although the precipitation trend has shown an overall minor increase, less seasonal and high inter-annual variation in precipitation has been experienced in the HKH region (Chen et al. 2013). Precipitation showed a significant increase during the winter and spring, but non-significant decrease during the summer and autumn seasons. Future projections of precipitation indicate a wetting trend with increases of 38 or $272 \mathrm{~mm}$ by 2100 under two scenarios (IPCC A2 and B1). Such climate diversity and possible future alteration estimated to modify the species richness pattern in this landscape where the impact of climate and topographic variability is identified as the major reasons (Panda et al. 2017; Tripathi et al. 2017).

With the advent of satellite remote sensing and related data products, and availability of several open source models, it is imperative to develop geospatial frameworks integrating different drivers of change and customise the analysis methods and models. Forest cover monitoring and change assessment can rely on remote sensing technology with ground measurements for verification (Behera et al. 2014). This enables researchers to compare and analyse the consistent changes across landscapes. Researchers have used the moderate resolution imaging spectro-radiometer derived TCC\% and the normalised difference vegetation index data to represent various forest formations and estimated their resilience in relation to the responsible variables (Bucini and Hanan 2007; Staver et al. 2011). The spatio-temporal changes in forest cover of the HKH region studied across the landscapes suggest that both the natural and anthropogenic forces played a key role (Houghton 2005; Rudel et al. 2005; Upadhyay et al. 2005; Roy et al. 2013; Murthy et al. 2016; Behera et al. 2018). In the current study, we have utilised the TCC $\%$ data to define various forest formations, and estimated their resilience by accounting to precipitation.

\section{Study area}

The HKH region encompasses all or parts of eight countries - Afghanistan, Bangladesh, Bhutan, China, India, Myanmar, Nepal and Pakistan (figure 1). This region lies between $16^{\circ} \mathrm{N}-40^{\circ} \mathrm{S}$ and $61-$ $105^{\circ} \mathrm{E}$ with $>3500 \mathrm{~km}$ stretch along the east-west direction. The HKH region consists of several parallel mountain ranges, i.e., the Karakoram, the Hengduan Mountains, the Himalayas, the Hindu Kush and the Tibetan Plateau. The sharp

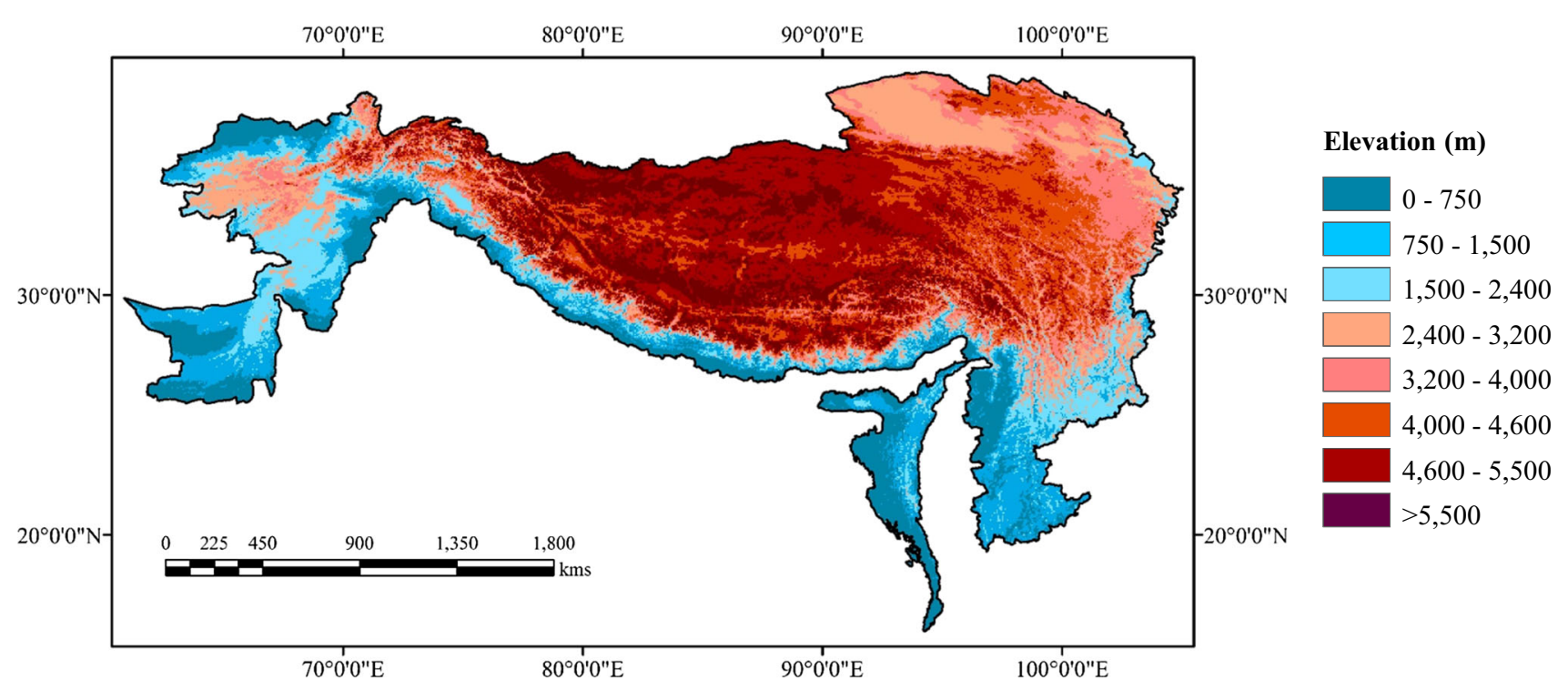

Figure 1. HKH region is spread over eight countries with the elevation above MSL. 
altitudinal gradient and topographic variations resulted in compressed ecoclimatic zones accommodating very rich biodiversity (Behera and Kushwaha 2007). The forest types vary along the elevation gradient such as tropical and sub-tropical rainforests; temperate broadleaf, deciduous or mixed; temperate coniferous, alpine moist and dry scrub; meadows; and desert steppe (Behera et al. 2002; Guangwei 2002). The forests of the $\mathrm{HKH}$ region support over $12 \%$ of the world's population and provide various ecosystem goods and services including freshwater, energy, timber, variety of bio-resources, etc. to one-fifth of world's population (Zomer et al. 2011; Ning et al. 2014). The rangelands of the HKH region are experiencing unprecedented pressure and deterioration due to four-fold increase in human and livestock population in the last 5-6 decades (Sharma et al. 2007).

\section{Materials and methods}

\subsection{Tree canopy cover for the year 2000, loss and gain during 2000-2012}

Here, we have estimated the precipitation-dependent forest cover resilience. The high-resolution TCC $\%$ data $(30 \mathrm{~m})$ for the year 2000 and the forest loss and gain data during 2000-2012 were downloaded from the Earth Engine Partner's database (http://earthenginepartners.appspot.com/). Mosaicking and extraction were done using the study area boundary to prepare the tree canopy cover and change maps (table 1). The tree canopy cover is defined as the canopy closure for all the vegetation taller than $5 \mathrm{~m}$ in height, and represented as the TCC $\%$ per $30 \mathrm{~m}$ grid cell ranging from 0 to $100 \%$ (Hansen et al. 2013). The TCC\% map for the year 2000 represents the percent of tree canopy cover in each cell or pixel for the year 2000. The forest cover loss data was encoded ranging from 1 to 12 , where the number indicates the year of TCC\% loss during 2000-2012; whereas the forest cover gain data was encoded as 0 and 1 that corresponds to 'no change' and 'gain during 2000-2012', respectively, having no information about the year-wise forest cover gain. The TCC\% loss and gain data only indicates the spatial location of forest canopy cover change, and does not account to change in TCC\%. All the data were resampled to $5 \mathrm{~km}$ for further analysis. The elevated Tibetan Plateau is almost devoid of forest cover beyond $5500 \mathrm{~m}$ elevation, and experiences $<-2^{\circ} \mathrm{C}$ mean annual temperature and about $100 \mathrm{~mm}$ mean annual precipitation (Singh and Singh 1987). Hence, these areas were masked out using elevation [digital elevation model (DEM) from the shuttle radar topographic mission (SRTM)] and temperature data to avoid any bias in further analysis (Hirota et al. 2011). For elevation data, the SRTM-derived DEM data was downloaded from the database of 'Consortium for Spatial Information (CGIAR-CSI)'. The spatial resolution of the data is $90 \mathrm{~m}$ (table 1). Mosaic and extraction by masking was done to extract the data for the $\mathrm{HKH}$ region.

\subsection{Climate data description and source}

The global precipitation and temperature data was downloaded from the climate research unit (CRU) database for the year 2000. The CRU (version TS3.21) data was constructed using the monthly observations from the meteorological stations across the world's land areas, primarily from three sources, i.e., (i) World Meteorological Organization (around 2200 stations during 2002-2009 and >2800 stations for unique precipitation measurements), (ii) Monthly climatic data for the world produced by US National Oceanographic and Atmospheric Administration (via its National Climatic Data Center) (average number of stations: 1500 during 2002-2009 with 2600 precipitation measurement stations), and (iii) World Weather Records decadal data publications that are exchanged between National Meteorological Services (around 1700 stations during 1991-2000) (Harris et al. 2014). The mean annual temperature and total annual precipitation were derived using the monthly data, which was then clipped using the study area boundary in the ArcGIS

Table 1. Data specifications as utilised in the study.

\begin{tabular}{llll}
\hline Data & \multicolumn{1}{c}{ Year } & Resolution & \multicolumn{1}{c}{ Data source } \\
\hline Canopy cover, forest loss-gain & 2000 and $2000-2012$ & $30 \mathrm{~m}$ & Earth-engine partners \\
Temperature and precipitation data & $2000-2010$ & $0.5^{\circ}$ & CRU data \\
SRTM DEM & 2000 & $90 \mathrm{~m}$ & CGIAR-CSI \\
\hline
\end{tabular}

CRU: climate research unit; CSI: consortium for spatial information. 
platform. The total annual precipitation varied between 13 and $5299.8 \mathrm{~mm}$ during 2010 (defining the variation in precipitation observed between all measured data in this region), where the moderateto-high precipitation areas were observed in northeast India, Myanmar, Bangladesh, Bhutan and northern Nepal; while the least precipitation was observed in Pakistan, Afghanistan, north India and northern part of China (figure S1). The range of mean annual temperature varied between $12^{\circ}$ and $27^{\circ} \mathrm{C}$, where the negative mean annual temperature was observed in the northern part of China, which are mostly cold desserts with no vegetation above $5500 \mathrm{~m}$ altitude.

\subsection{Estimation of forest cover resilience}

The tree canopy cover map was categorised into four forest categories depending on the dominance TCC $\%$ ( $0 \%$ as treeless state, $1-10 \%$ as grass savanna, $11-39 \%$ as scrub and $\geq 40 \%$ as forest). To estimate the forest cover resilience, we have adopted the same technique as Hirota et al. (2011), where they performed logistic regression and which then used to fit to a second-order polynomial equation to derive the corresponding resilience. We have used the ArcGIS platform to convert the $\mathrm{TCC} \%$ data in vector and further to extract the corresponding precipitation values. We performed the logistic regression and then fitted the secondorder polynomial equation. Using the coefficients of the polynomial equation, we calculated the value of $z$ (precipitation-dependent parameter) and the corresponding resilience probability using the following equations:

$$
\begin{gathered}
P(\text { category }=y)=\frac{1}{1+\exp (-z)}, \\
z=\beta_{0}+\beta_{1} x_{+} \beta_{2} x^{2},
\end{gathered}
$$

where $y$ is either treeless, grassland, scrub or forest; $\beta_{0}$ is a constant; $\beta_{1,2}$ are coefficients; and $x$ is the precipitation.

Similarly, we also tried computing the resilience probability accounting ' $z$ ' to temperature as an independent variable. The basic principle of the logistic regression is that it transmits the inputoutput relations using the binary presence $(Y=1)$ and absence $(Y=0)$ data or here, a particular forest cover type with the independent variable, i.e., precipitation and temperature. Now, the linear or non-linear regression can be used to find the unknown parameters in the function.
Table 2. Area estimates of tree canopy cover for the year 2000.

\begin{tabular}{ll}
\hline Class $($ TCC\%) & Area in $\mathrm{km}^{2}($ area $\%)$ \\
\hline Treeless $(0)$ & $3,450,100(79.79)$ \\
Grass $(1-10)$ & $13,600(0.32)$ \\
Scrub $(11-39)$ & $92,850(2.15)$ \\
Forest $(40-100)$ & $767,200(17.74)$ \\
Total & $4,323,750$ \\
\hline
\end{tabular}

\section{Results and discussion}

The HKH region is dominated by treeless area with $79.79 \%$ of the total geographical area (table 2; figure 2). The remaining $20.21 \%$ area was covered by forest, scrub and grasslands with $767,200 \mathrm{~km}^{2}$ (17.74\%), $92,850 \mathrm{~km}^{2}(2.15 \%)$ and $13,600 \mathrm{~km}^{2}$ $(0.32 \%)$, respectively. The country-wise forest area statistics showed that the maximum contribution was by Myanmar $\left(263,775 \mathrm{~km}^{2}\right)$ followed by India $\left(201,550 \mathrm{~km}^{2}\right)$ and China $\left(199,975 \mathrm{~km}^{2}\right)$ and the least contribution was by Afghanistan $\left(2000 \mathrm{~km}^{2}\right)$ (table 3 ). In case of both scrub and grassland spread, the maximum contribution was by China followed by India and Myanmar (figure 2). The maximum treeless area was accounted to China, which was $>62 \%$ of the total treeless area (table 3 ). The HKH region experienced an overall loss of $11,250 \mathrm{~km}^{2}$ forests during $2000-2010$ that can be separated to 13,225 and $1975 \mathrm{~km}^{2}$ forest loss and gain, respectively (Murthy et al. 2016). Out of the total forest loss, Myanmar alone accounted to $51 \%$ forest loss, whereas in India $24 \%$ forest loss took place (table 3). According to the Forest Survey of India report (FSI 2013), in Arunachal Pradesh alone, nearly $1000 \mathrm{~km}^{2}$ forest loss took place during the study period. Behera et al. (2018) studied the deforestation in the entire northeast India, and observed a combined loss of $3300 \mathrm{~km}^{2}$ of forest, scrub and grassland during 1985-2005. In Myanmar, $0.31 \mathrm{~m}$ ha of forest loss was observed during 2000-2010 due to the overuse of forest resources (FAO 2010). On the other hand, 3.41\% increase in net forest cover is reported in China during 2000 2013. Similarly, Bhutan has reported forest gain of $0.22 \%$ per year during 1990-2010 (Gilani et al. 2015; Li et al. 2017).

Since we observed a better regression value $\left(R^{2}\right)$ for precipitation than temperature, we used only precipitation to predict the resilience in this study. The scatter plot of TCC\% w.r.t. precipitation is given in figure 3 with the corresponding curve of 


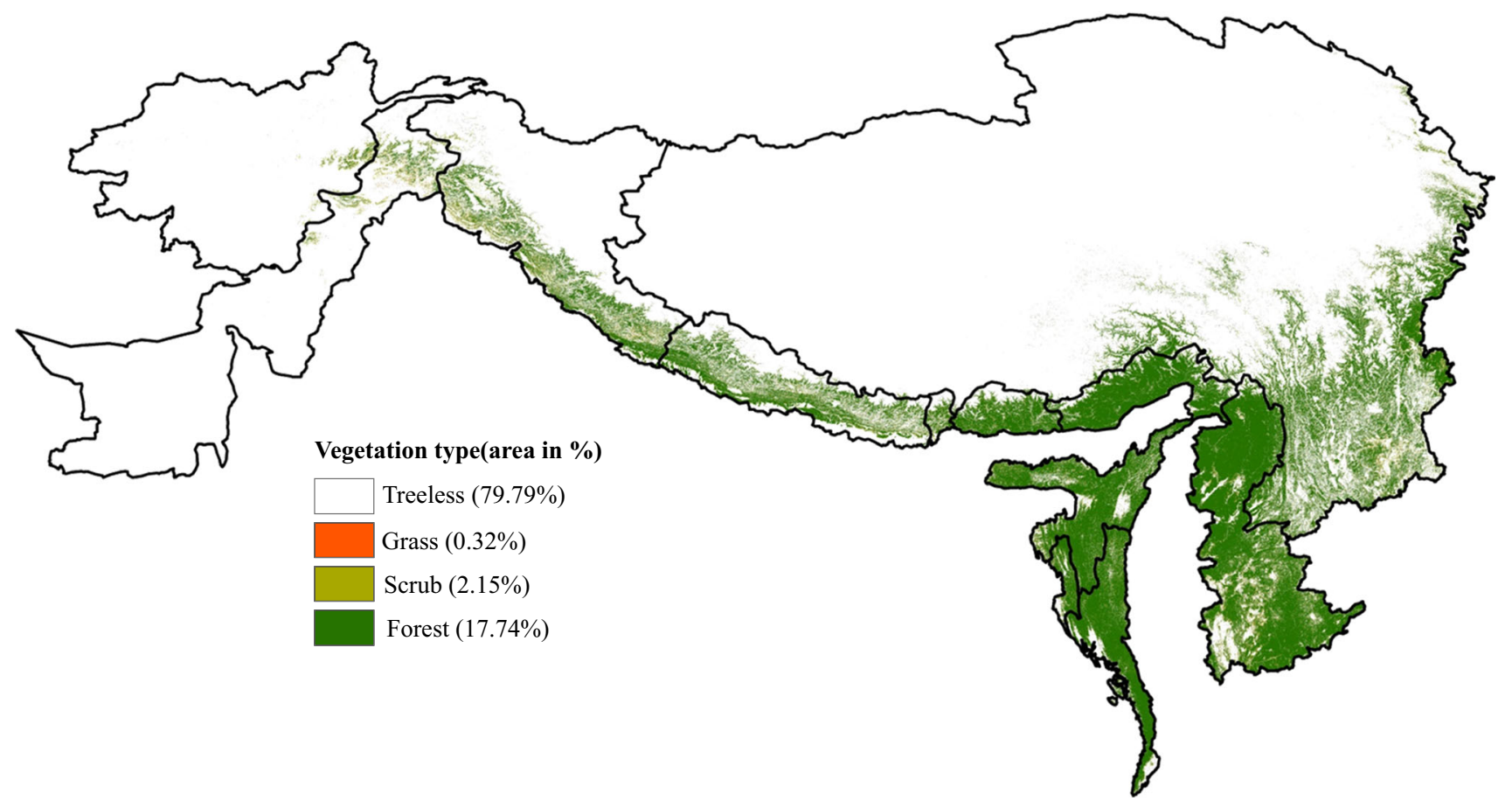

Figure 2. Tree canopy cover map categorised into four vegetation types of the HKH region.

Table 3. Country-wise area estimates of tree canopy cover for the year 2000 (in $\mathrm{km}^{2}$ ).

\begin{tabular}{lrrrr}
\hline Country name & Treeless & Grass & Scrub & Forest \\
\hline Afghanistan & 415,381 & 175 & 2225 & 2000 \\
Pakistan & 424,664 & 1225 & 5325 & 6325 \\
India & 297,522 & 3275 & 21,300 & 201,550 \\
Nepal & 79,145 & 1000 & 8325 & 58,600 \\
China & $2,168,143$ & 4850 & 35,400 & 199,975 \\
Bhutan & 13,497 & 175 & 1700 & 24,525 \\
Bangladesh & 3616 & 325 & 1150 & 10,450 \\
Myanmar & 48,132 & 2575 & 17,425 & 263,775 \\
\hline
\end{tabular}

resilience probability $(\mathrm{Pr})$ estimated by applying the logistic regression. The corresponding $\beta$ coefficient values for each forest type and the Nagelkerke $R^{2}$ of logistic regression are given in table 4 . With the $R^{2}$ values noted as $0.42,0.11,0.12$ and 0.44 for forest, scrub, grass and treeless, respectively, in table 4 , it can be inferred that the precipitation was able to explain the TCC\% distribution for forest and treeless areas fairly, but failed to explain the distribution of grassland and scrub. This could be due to two possible reasons: (i) the presence of large treeless data points even at higher precipitation areas where the occurrence of scrub and grassland data points was least, and (ii) the absence of gradual increasing trend in TCC $\%$ with the precipitation, as observed by
Hirota et al. (2011). Moreover, the HKH region has large variations due to frequent alteration in elevation, which makes it a topographically rugged landscape and creates sharp transition in the closely spaced climatic zones supporting different forest cover formations at very short intervals. Further, the distinct climate condition was observed in the southern and northern aspects. In the HKH region, large forest data points were observed at 500-1700 mm precipitation range, coinciding with larger distribution of both scrub and grasslands. The overlapping precipitation ranges of treeless and forest cover with the scrub and grassland could have led to their insignificant presence in the HKH region. However, the presence of sufficient forest cover data points even at higher precipitation zones compared to scrub and grassland allowed in modelling their presence. The mid-value of forest cover resilience (i.e., $\operatorname{Pr}=0.5$ ) was observed around $1650 \mathrm{~mm}$ precipitation, below which a larger proportion of forests lies and estimated to have lower resilience. The mid Pr value for treeless state was observed around $1470 \mathrm{~mm}$, which indicates that the change prone treeless areas have higher precipitation value than this. However, the maximum Pr values for scrub and grassland were estimated to be 0.15 and 0.25 , respectively, which could be attributed to their overlapping in precipitation ranges with forest and treeless areas. 


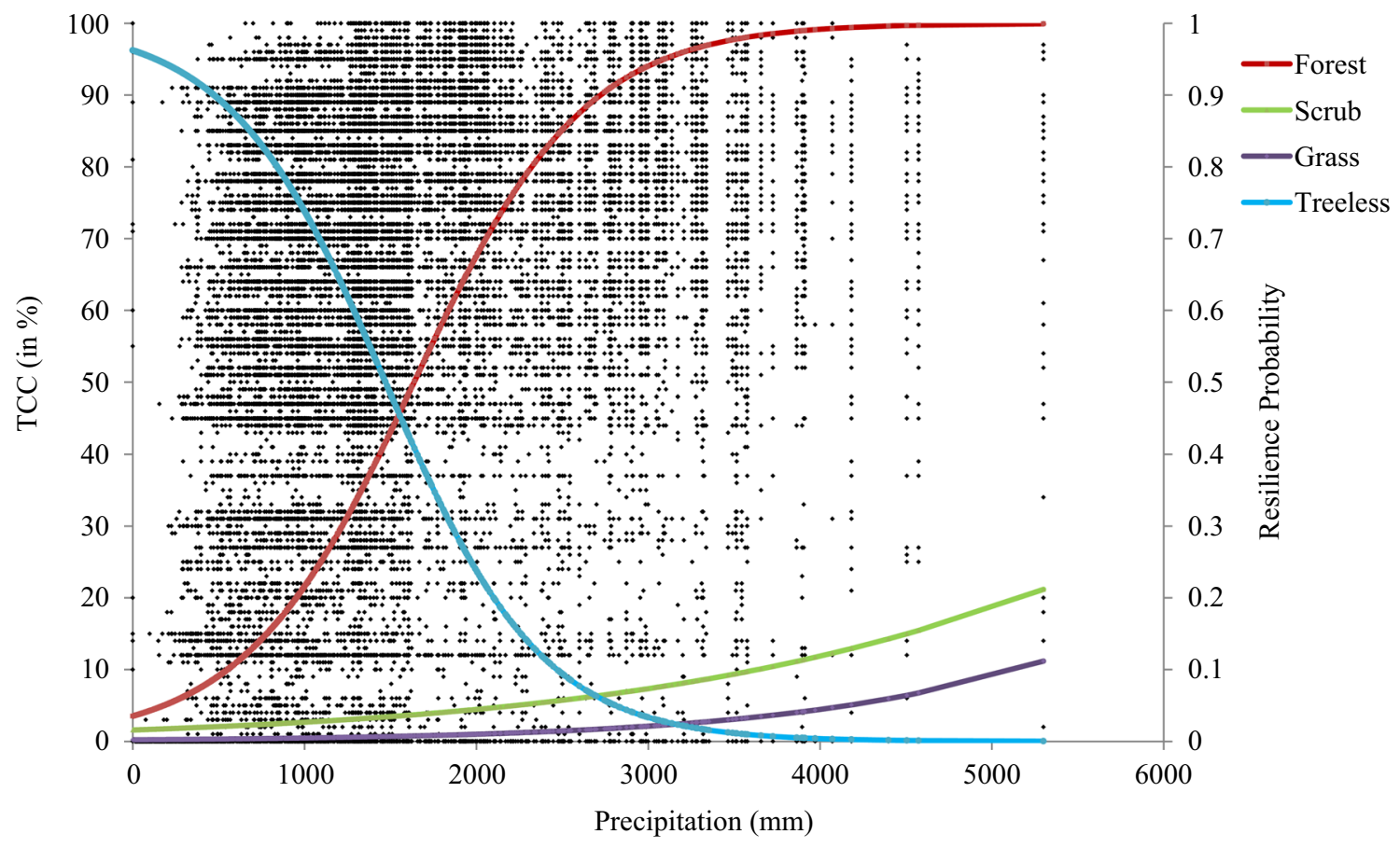

Figure 3. Probability of resilience (secondary axis) of different vegetation types (TCC\% in primary axis) w.r.t. total annual precipitation $(\mathrm{mm})$ (horizontal axis).

Table 4. Estimated coefficients and the Nagelkerke $R^{2}$ of the logistic regressions predicting vegetation types as a function of total annual precipitation and mean annual temperature.

\begin{tabular}{llrrrr}
\hline Variable & $\begin{array}{c}\text { Vegetation } \\
\text { type }\end{array}$ & $\beta_{0}$ & $\beta_{1}$ & $\beta_{2}$ & $R^{2}$ \\
\hline Rainfall & Forest & -3.316 & 0.002 & 0.000 & 0.42 \\
& Scrub & -4.127 & 0.001 & 0.000 & 0.11 \\
& Grass & -6.126 & 0.001 & 0.000 & 0.12 \\
& Treeless & 3.238 & -0.002 & 0.000 & 0.44 \\
\hline
\end{tabular}

The estimated resilience probabilities of four forest types are given in table 5 and figure 4 . The values of $\operatorname{Pr}$ were categorised at an interval of 0.05 and their corresponding area spread was mentioned. About $375 \mathrm{~km}^{2}(<0.05 \%$ of the total forest cover) area was estimated to have $\operatorname{Pr}<0.05$, indicating the forests with the highest tendency of transition to its alternative stable state of scrub with $14,875 \mathrm{~km}^{2}$ having Pr between 0.05 and 0.1 (figure 5). Around $59.3 \%$ of the total forests showed $\operatorname{Pr}<0.5$ owing to their presence in the lower precipitation range $(<1650 \mathrm{~mm})$ in northeast India, northern part of India, Nepal, Bhutan and Pakistan, southeastern parts of China and Myanmar. Rest of the forests (around 40.65\%) with $\operatorname{Pr}>0.5$ were mostly found in north Nepal, Bhutan, northeast India, Bangladesh, western and north Myanmar having wetter climate. About $25,200 \mathrm{~km}^{2}$ treeless areas were identified as having least resiliency $(\operatorname{Pr}<0.05)$, and could exhibit transition tendency to its alternative stable state of grassland (figure 6). These treeless areas were mostly seen in western Myanmar, northern India and Bangladesh. Only $4.6 \%$ of the total treeless areas showed the lower resilience $(\mathrm{Pr}<0.5)$ observed in areas with sufficient amount of precipitation, whereas rest $94.4 \%$ areas exhibited the higher resilience probability to be in the same state as can be seen in the drier parts of China, north India, Pakistan and Afghanistan (figure 6).

The majority of the scrub and grasslands observed to have less resilience probability indicate their transition to the alternative forest state with lower TCC\%, whereas the moderate and 
Table 5. Area estimate (in $\mathrm{km}^{2}$ ) of treeless and various meta-stable states of tree canopy cover (grass savanna, scrub savanna and forest savanna) resilience probabilities (inversely, change proneness) for the year 2010.

\begin{tabular}{lrrrr}
\hline $\begin{array}{c}\text { Resilience } \\
\text { Probability }\end{array}$ & $\begin{array}{r}\text { Treeless to } \\
\text { Grass }\end{array}$ & $\begin{array}{c}\text { Grass to Treeless } \\
\text { \& Scrub }\end{array}$ & $\begin{array}{c}\text { Scrub to Grass } \\
\text { \& Forest }\end{array}$ & $\begin{array}{r}\text { Forest to } \\
\text { Scrub }\end{array}$ \\
\hline $0-0.05$ & 25200 & 13375 & 80650 & 375 \\
$0.05-0.10$ & 11350 & 200 & 10950 & 14875 \\
$0.10-0.15$ & 7100 & 25 & 1025 & 61950 \\
$0.15-0.20$ & 11625 & & 125 & 51500 \\
$0.20-0.25$ & 8550 & & 100 & 68950 \\
$0.25-0.30$ & 12875 & & & 35700 \\
$0.30-0.35$ & 8050 & & & 80175 \\
$0.35-0.40$ & 9025 & & & 53275 \\
$0.40-0.45$ & 20875 & & & 50475 \\
$0.45-0.50$ & 26800 & & & 37875 \\
$0.50-0.55$ & 32425 & & & 21700 \\
$0.55-0.60$ & 61025 & & & 22450 \\
$0.60-0.65$ & 68025 & & & 42100 \\
$0.65-0.70$ & 61175 & & & 35700 \\
$0.70-0.75$ & 107050 & & & 13050 \\
$0.75-0.80$ & 166825 & & & 19650 \\
$0.80-0.85$ & 172100 & & & 23750 \\
$0.85-0.90$ & 354600 & & & 54100 \\
$0.90-0.95$ & 866400 & & & 57050 \\
$0.95-1$ & 500775 & & & \\
\hline
\end{tabular}

Rest of the treeless areas $\left(918,250 \mathrm{~km}^{2}\right)$ belongs to cold deserts with $0 \%$ TCC located above $5000 \mathrm{~m}$ altitude received $<1200 \mathrm{~mm}$ precipitation and below $<-2{ }^{\circ} \mathrm{C}$ temperature. Colour is used to highlight the major observations as: (i) treeless to grass - orange colour: least resilient treeless area (highest change proneness to grass); cream colour: less resilient treeless area (low change proneness to grass); light brown: resilient treeless area; (ii) grass to treeless and scrub - cream colour: change prone grass towards treeless; orange: resilient grass cover; yellowish: change prone grass towards scrub; (iii) scrub to grass and forest - orange: change prone scrub towards grass, dark yellow: resilient scrub cover; yellowish green: change prone scrub towards forest; (iv) light shade of dark yellow: highly change prone forest cover towards scrub; olive green: less change prone forest towards scrub; green: resilient forest cover.

fewer areas were observed to have higher probability values. Keeping either-end transition probability, the scrub and grasslands with the highest range of resilience probability were attributed to change-proneness to forest and scrub with 100 and $25 \mathrm{~km}^{2}$, respectively (table 5 ). On the other end, with the lowest resilience probability range, $13,375 \mathrm{~km}^{2}$ grassland and $80,650 \mathrm{~km}^{2}$ scrubs showed change- proneness to treeless and grassland state, respectively. Scrub areas change-proneness to forests was observed in zones with the higher precipitation in Myanmar, Nepal, Bhutan and northeast India and change proneness to grassland was observed in the drier parts of northern India, Nepal and Pakistan and Eastern China (figure 7). A similar pattern was also seen for grassland, where they occupied the wetter zones of northeast India and Myanmar showing the transition probability to scrubs, and drier areas of China and north India showing the transition tendency to treeless state (figure 8).
Timely deforestation and afforestation in the parts of China, Myanmar, northeast India and Nepal are very common according to the countries forest management policies (www.forestlegality. org/). Murthy et al. (2016) identified an overall deforestation of $11,250 \mathrm{~km}^{2}$ in HKH region; where TCC $\%$ was decreased by $13,225 \mathrm{~km}^{2}$, whereas TCC $\%$ was increased by 1975, 50, 650 and $5375 \mathrm{~km}^{2}$ in treeless, grassland, scrub and forest areas, respectively, during 2000-2010. The Pr values of these points where TCC\% changed were examined through these changes and attributed to possible anthropogenic activities (table 6; figure 9). From table 6 , it can be observed that majority $\left(7050 \mathrm{~km}^{2}\right)$ of the TCC\% loss took place in forest areas having less resilience $(\operatorname{Pr}<0.5)$, whereas $5625 \mathrm{~km}^{2}$ forest areas have undergone TCC loss while having higher resilience probability $(\mathrm{Pr}>0.5)$. Only $25 \mathrm{~km}^{2}$ forests with least resilience probability have experienced TCC loss during 2000-2010. However, change in TCC\% 


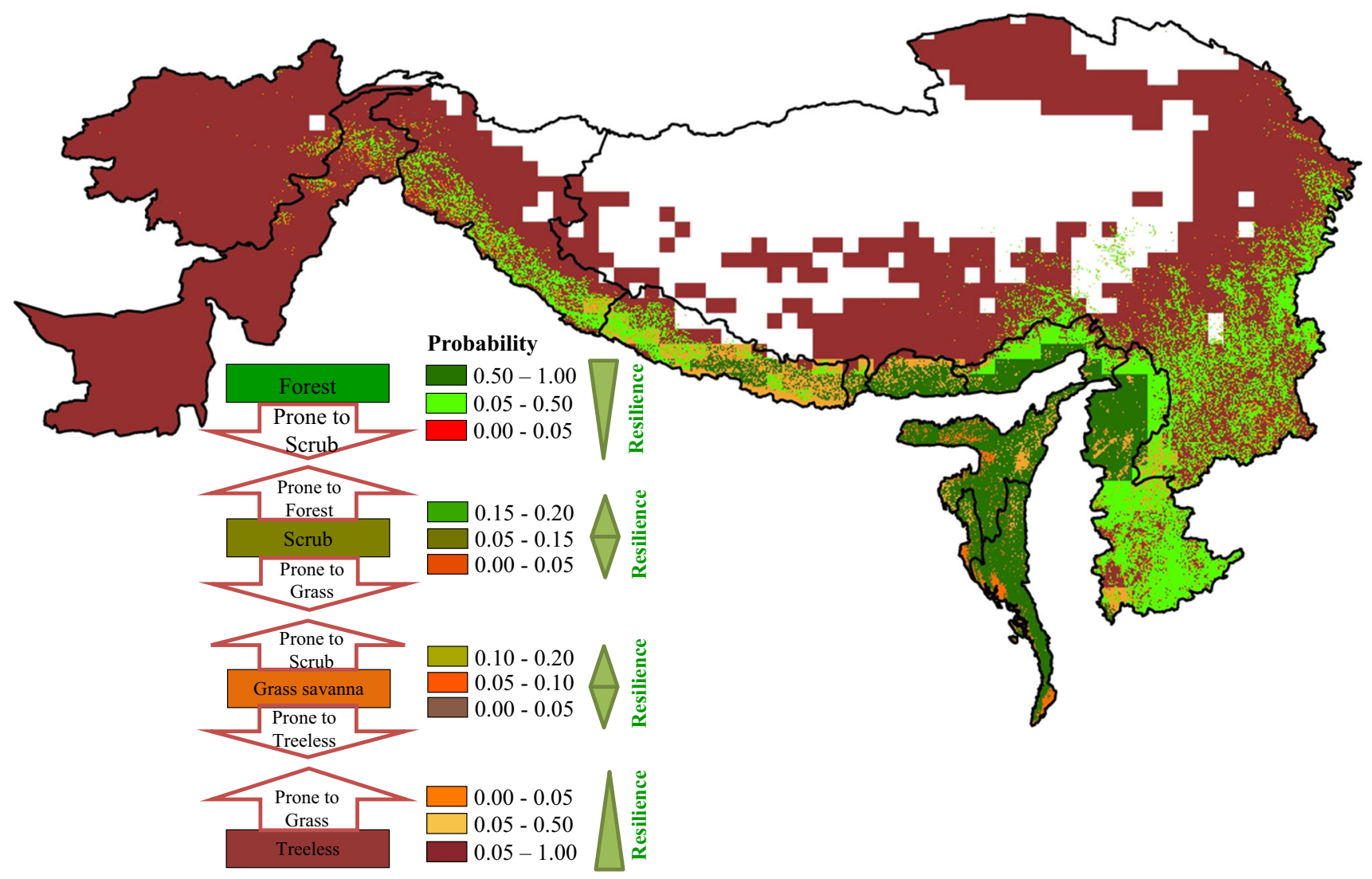

Figure 4. Tree canopy cover resilience map.

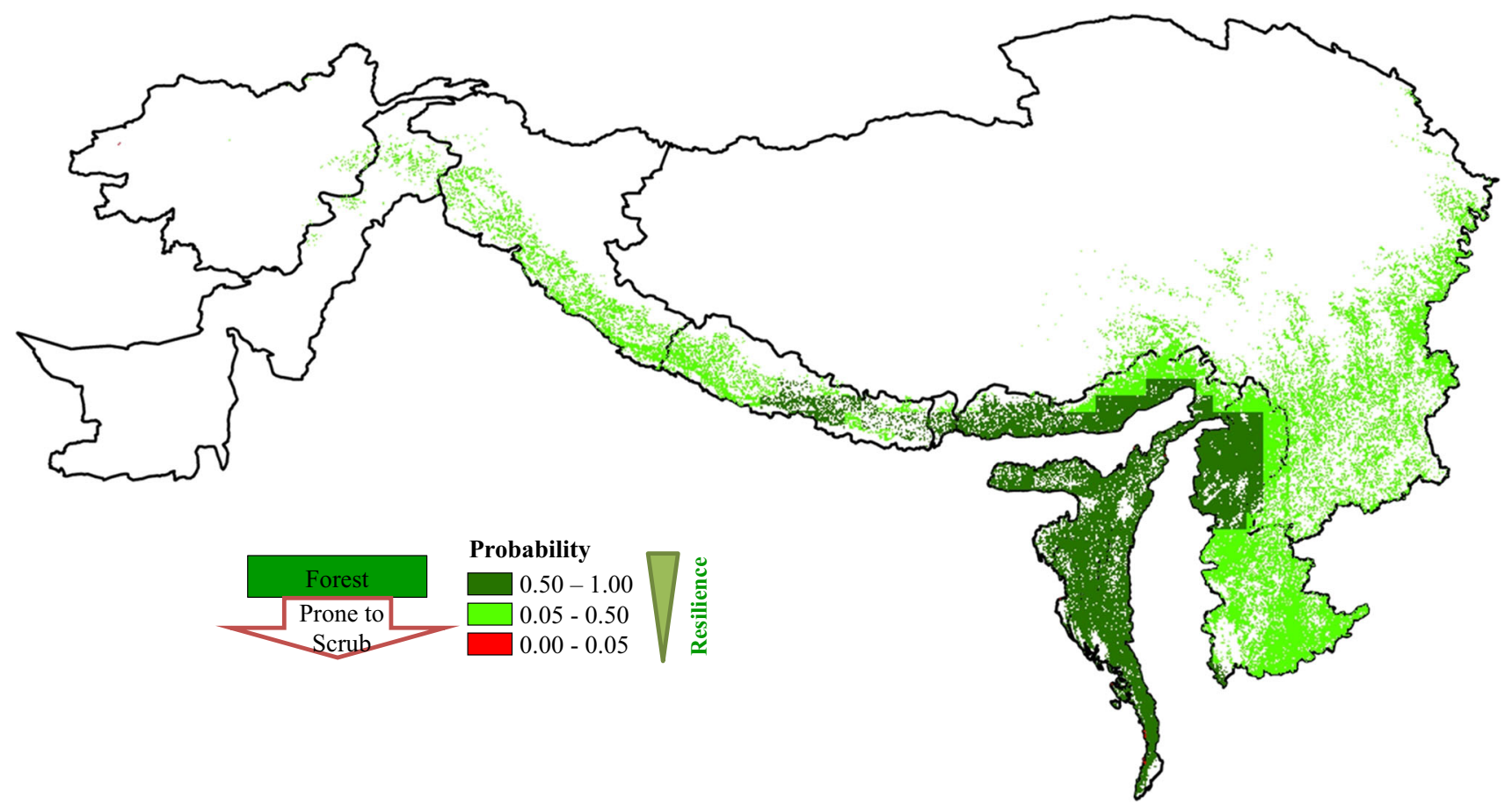

Figure 5. Forest cover resilience map.

was observed negligible in grassland and scrub in comparison to forest and treeless areas. About 325 and $1000 \mathrm{~km}^{2}$ treeless areas having least
$(\operatorname{Pr}<0.05)$ and moderate $(0.05<\operatorname{Pr}<0.5)$ resilience probability values, respectively, have undergone TCC rise, which has $875 \mathrm{~km}^{2}$ area estimation 


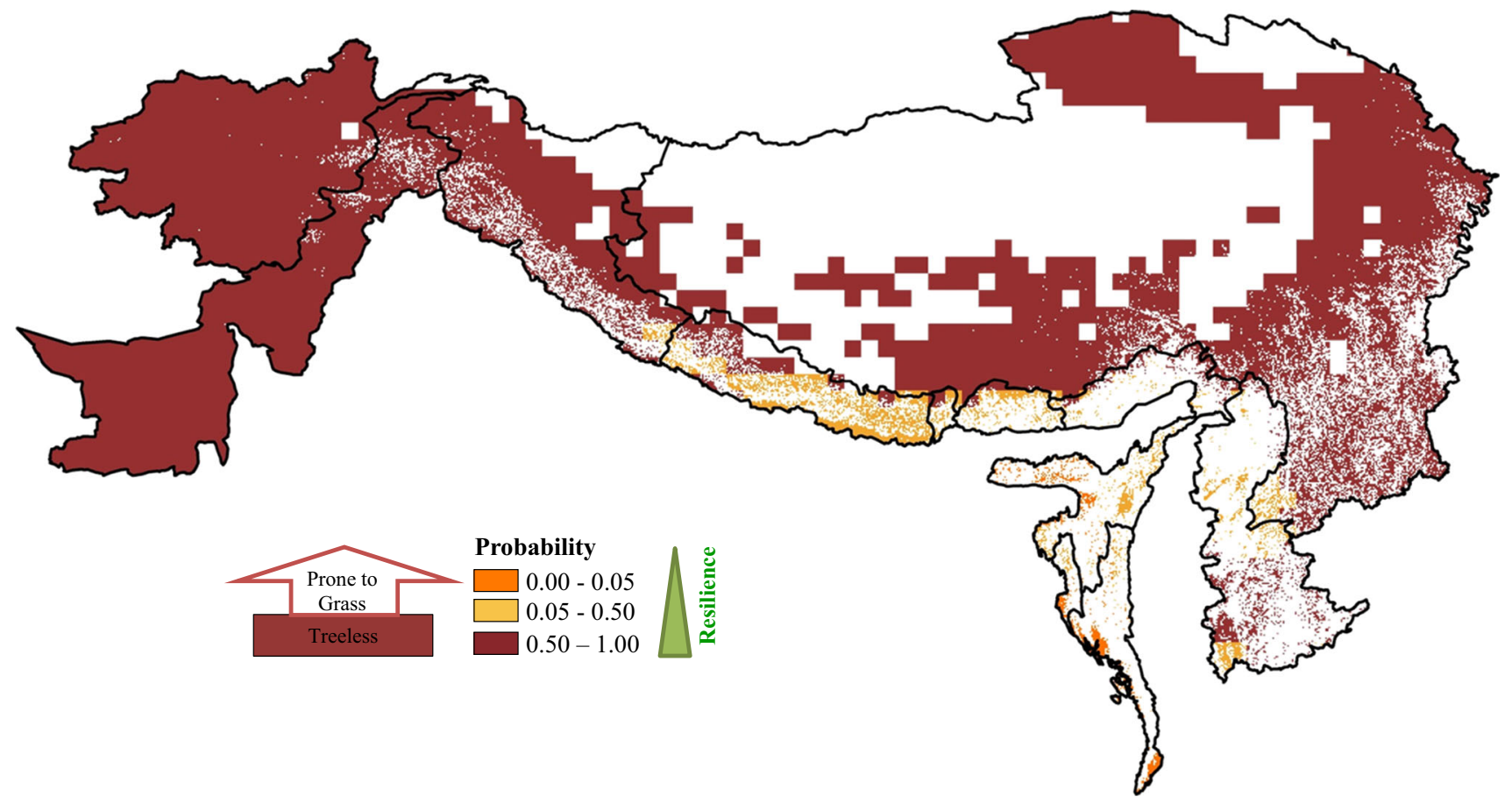

Figure 6. Resilience map of treeless state.

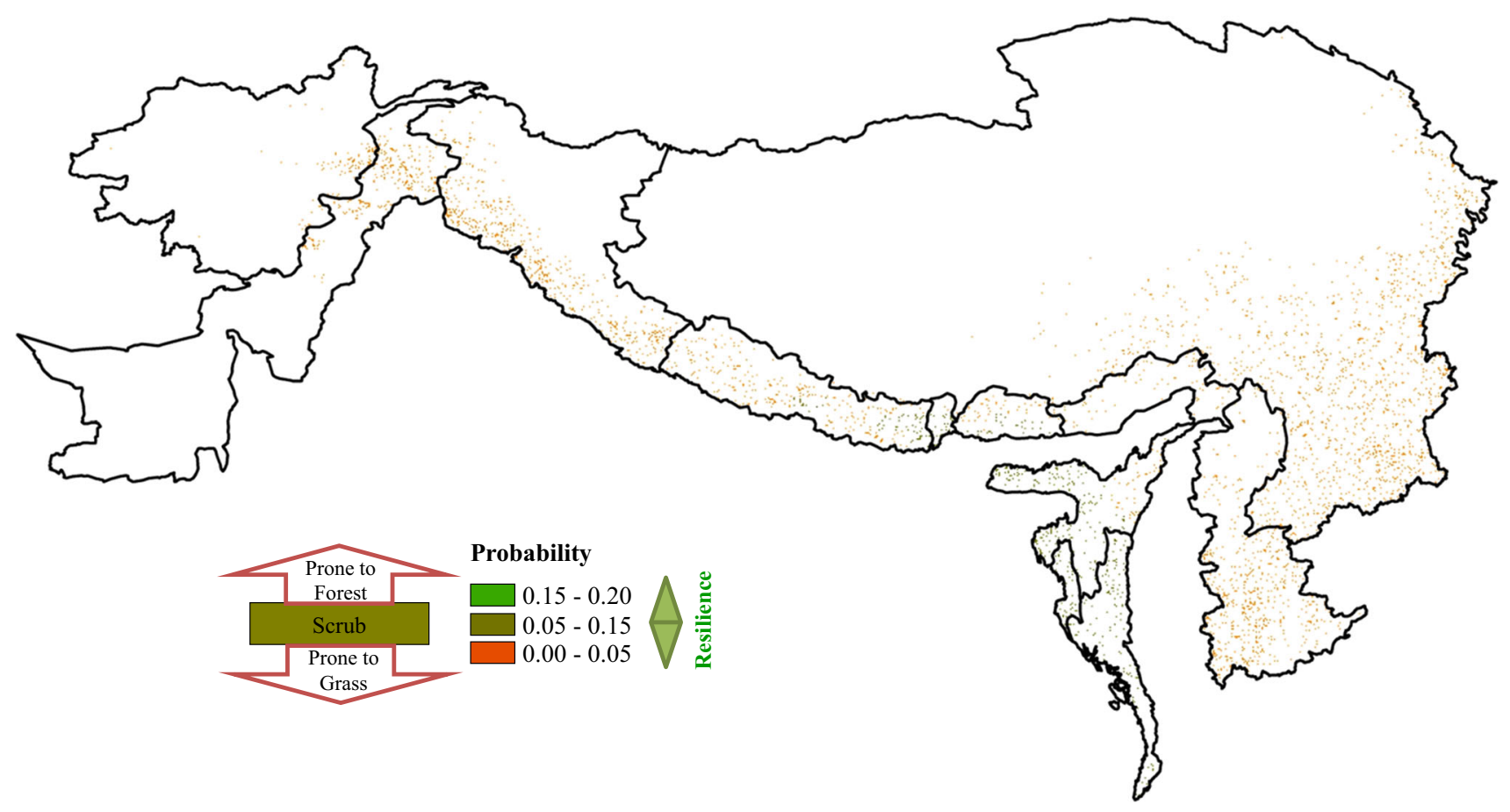

Figure 7. Resilience map of scrub.

under the higher resilience probability. Increases in TCC $\%$ in forest areas were observed as 2225 and $3275 \mathrm{~km}^{2}$ having the moderate and higher resilience. Most of the changes in TCC\% were observed in northeast India and Myanmar, which could be due to the anthropogenic activities such 


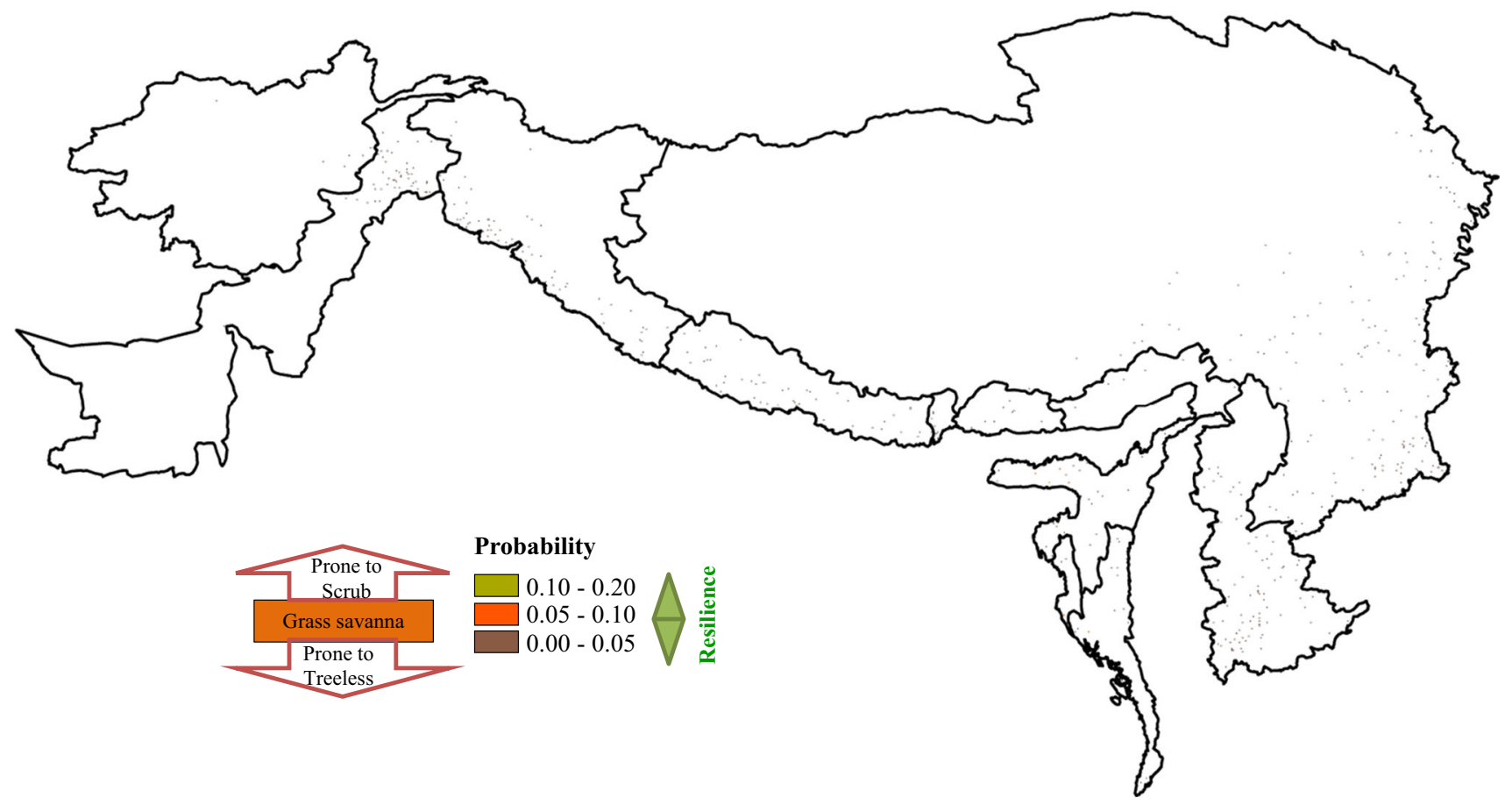

Figure 8. Resilience map of grassland.

Table 6. Area estimate (in $\mathrm{km}^{2}$ ) of points where TCC\% increased and decreased during 20002010 with the corresponding resilience in the year 2000.

\begin{tabular}{|c|c|c|c|c|c|c|c|c|}
\hline \multirow[b]{2}{*}{$\begin{array}{l}\text { Resilience } \\
\text { Probability }\end{array}$} & \multicolumn{4}{|c|}{ TCC\% Decreased } & \multicolumn{4}{|c|}{ TCC\% Increased } \\
\hline & $\begin{array}{l}\text { Treeless } \\
\text { to Grass }\end{array}$ & $\begin{array}{l}\text { Grass to } \\
\text { Treeless } \\
\text { \& Scrub }\end{array}$ & $\begin{array}{c}\text { Scrub to } \\
\text { Grass \& } \\
\text { Forest }\end{array}$ & $\begin{array}{c}\text { Forest } \\
\text { to } \\
\text { Scrub }\end{array}$ & $\begin{array}{c}\text { Treeless } \\
\text { to } \\
\text { Grass }\end{array}$ & $\begin{array}{l}\text { Grass to } \\
\text { Treeless } \\
\text { \& Scrub }\end{array}$ & $\begin{array}{c}\text { Scrub to } \\
\text { Grass \& } \\
\text { Forest }\end{array}$ & $\begin{array}{c}\text { Forest } \\
\text { to } \\
\text { Scrub }\end{array}$ \\
\hline $0-0.05$ & 0 & 50 & 300 & 25 & 325 & 50 & 50 & 0 \\
\hline $0.05-0.10$ & \multirow{9}{*}{0} & 0 & \multirow{3}{*}{175} & \multirow{9}{*}{$\begin{array}{r}7050 \\
(\mathrm{MC}: 1)\end{array}$} & \multirow{9}{*}{$\begin{array}{r}1000 \\
(\mathrm{MC}: 3)\end{array}$} & 0 & \multirow{3}{*}{225} & \multirow{9}{*}{$\begin{array}{r}2225 \\
(\mathrm{MC}: 5)\end{array}$} \\
\hline $0.10-0.15$ & & 0 & & & & 0 & & \\
\hline $0.15-0.20$ & & & & & & & & \\
\hline $0.20-0.25$ & & & 0 & & & & 0 & \\
\hline $0.25-0.30$ & & & & & & & & \\
\hline $0.30-0.35$ & & & & & & & & \\
\hline $0.35-0.40$ & & & & & & & & \\
\hline $0.40-0.45$ & & & & & & & & \\
\hline $0.45-0.50$ & & & & & & & & \\
\hline $0.50-0.55$ & \multirow{10}{*}{0} & & & \multirow{10}{*}{$\begin{array}{r}5625 \\
(\mathrm{MC}: 2)\end{array}$} & \multirow{10}{*}{$\begin{array}{r}875 \\
(\mathrm{MC}: 4)\end{array}$} & & & \multirow{10}{*}{$\begin{array}{r}3275 \\
(\mathrm{MC}: 6)\end{array}$} \\
\hline $0.55-0.60$ & & & & & & & & \\
\hline $0.60-0.65$ & & & & & & & & \\
\hline $0.65-0.70$ & & & & & & & & \\
\hline $0.70-0.75$ & & & & & & & & \\
\hline $0.75-0.80$ & & & & & & & & \\
\hline $0.80-0.85$ & & & & & & & & \\
\hline $0.85-0.90$ & & & & & & & & \\
\hline $0.90-0.95$ & & & & & & & & \\
\hline $0.95-1$ & & & & & & & & \\
\hline
\end{tabular}

Map code (MC) w.r.t. figure 9.

as shifting cultivation practices, rubber and other forest plantation in northeast India, and higher annual allowable cut with intense anthropogenic activities in Myanmar (figure 9) (Maithani 2005; Ramakrishnan 2007; Songer et al. 2009; Saha et al. 2010; Mon et al. 2012). 


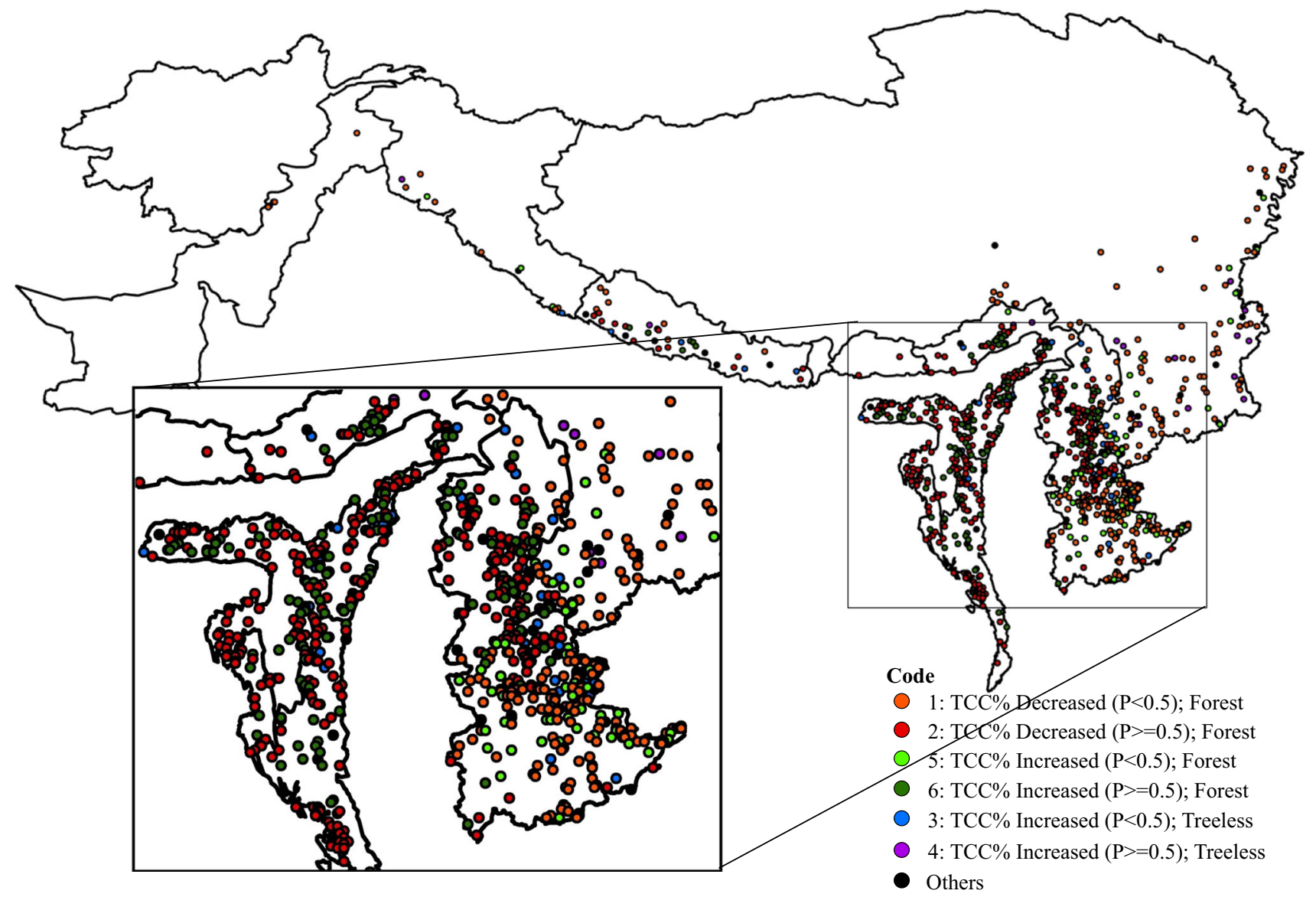

Figure 9. Map showing some location points where TCC\% changed (increased/decreased) during 2000-2010.

\section{Conclusions}

The arrangement of mountains in the HKH region makes it a highly variable landscape that created distinct differences in the spatio-temporal distribution in precipitation and temperature, i.e., climate zones and the corresponding forest types. Around $873,650 \mathrm{~km}^{2}$ forest area was observed in the HKH region in the year 2000, which experienced change (both loss and gain) in TCC\% of 13,225 and $8025 \mathrm{~km}^{2}$, respectively, during 2000-2010. In the $\mathrm{HKH}$ region, places having extreme temperature with low precipitation were mostly devoid of forest cover as seen in Pakistan, Afghanistan and northern parts of China. The results clearly showed that the precipitation has much bearing on forest and treeless state resilience in comparison to scrub and grassland. The forest cover resilience $(\mathrm{Pr}>$ $0.5)$ was observed having $>1650 \mathrm{~mm}$ precipitation. The majority of forest cover $(>59.3 \%)$ observed as less resilient is correlated with the lower precipitation range. Around $1 \%$ of treeless areas observed to have least resilience and more than $94.4 \%$ of the areas with $<470 \mathrm{~mm}$ precipitation were observed to be resilient $(\operatorname{Pr}>0.5)$. The resilient and change proneness estimation proved that the utility of the method to be more fitting for forest and treeless categories than the grassland and scrub. However, the model performance for the grassland and scrub could be improved by examining more factors or employing the more critical process-based models as dynamic vegetation models. The higher variability in input data in the present study also could lead to the lesser sensitivity of the analysis for grassland and scrub. This may need a landscape level analysis for better performance of the model.

\subsection{Management and forest resilience}

Globalisation and climate change have an increasing influence on the stability of fragile mountain ecosystems and the livelihoods of mountain people. In 2007, the IPCC recognised the HKH region as a 'data-deficient area'. In the last few decades, the $\mathrm{HKH}$ region has undergone rapid economic, social and environmental changes triggering changes in forest cover, land use, ecosystem and their services. 
This study utilised a geospatial framework to estimate the precipitation-driven tree canopy cover resilience or proneness in the HKH region. The tree canopy cover change proneness and resilience map showed clearly the areas having different levels of change and resilience potentials. Interestingly, most areas in northeast India, western Myanmar, Bhutan and Nepal showed resilient to forest change owing to climate attributes. The areas showing high forest change proneness are located in lower Siwalik foothills and Myanmar, and hence qualify urgent attention for conservation.

\section{Acknowledgements}

The financial support (contract no. CONID00606) from the International Centre for Integrated Mountain Development, Kathmandu, Nepal for carrying out the work is thankfully acknowledged. The authors are thankful to Director, IIT Kharagpur and Head, CORAL, IIT Kharagpur for providing the facilities to carry out the study.

\section{References}

Anderson-Teixeira K, Miller A D, Mohansk J E, Hudiburg T W, Duval B D and DeLucia E H 2013 Altered dynamics of forest recovery under a changing climate; Glob. Change Biol. 19 2001-2021, https://doi.org/10.1111/gcb.12194.

Behera M D and Kushwaha S P S 2007 An analysis of altitudinal behavior of tree species in Subansiri district, Eastern Himalaya; Biodivers. Conserv. 16 1851-1865.

Behera M D, Kushwaha S P S and Roy P S 2002 High plant endemism in an Indian Hotspot- Eastern Himalaya; Biodivers. Conserv. 11(4) 669-682.

Behera M D, Patidar N, Chitale V S, Behera N, Gupta D, Matin S, Tare V, Panda S N and Sen D J 2014 Increase of agricultural patch contiguity over past three decades in Ganga River Basin, India; Curr. Sci. 107(3) 502-515.

Behera M D, Tripathi P, Das P, Srivastava S K, Roy P S, Joshi C, Behera P R, Deka J, Kumar P, Khan M L, Tripathi O P, Dash T and Krishnamurthy Y V N 2018 Remote sensing based deforestation analysis in Mahanadi and Brahmaputra river basin in India since 1985; J. Environ. Manag. 206 1192-1203, https://doi.org/10.1016/j. jenvman.2017.10.015

Bucini G and Hanan N P 2007 A continental-scale analysis of tree cover in African savannas; Glob. Ecol. Biogeogr. 16 593-605.

Chen H, Zhu Q, Peng C, Wu N, Wang Y, Fang X, Gao Y, Zhu D, Yang G, Tian J, Kang X, Piao S, Ouyang H, Xiang W, Luo Z, Jiang H, Song X, Zhang Y, Yu G, Zhao X, Gong P, Yao T and Wu J 2013 The impacts of climate change and human activities on biogeochemical cycles on the Qinghai-Tibetan Plateau; Glob. Chang. Biol. 19 2940-2955, https://doi.org/10.1111/gcb.12277.
Chitale V S and Behera M D 2014 Analysing land and vegetation cover dynamics during last three decades in Katerniaghat wildlife sanctuary, India; J. Earth Syst. Sci. 123(7) 1467-1479.

Dale V H, Lugo A E, MacMahon J A and Pickett S T A 1998 Ecosystem management in the context of large, infrequent disturbances; Ecosystems 1 546-557.

Das P, Behera M D and Murthy M S R 2017 Forest fragmentation and human population varies logarithmically along elevation gradient in Hindu Kush Himalaya - utility of geospatial tools and free data set; J. Mount. Sci. 14 2432-2447, https://doi.org/10.1007/s11629-016-4159-0.

FAO 2010 Global forest resources assessment - 2010 report; Compiled by Earth Policy Institute from U.N. Food and Agriculture Organization, Rome, Italy.

Folke C, Carpenter S, Walker B, Scheffer M and Elmqvist $\mathrm{T}$ et al. 2004 Regime shifts, resilience, and biodiversity in ecosystem management; Ann. Rev. Ecol. Evol. S. 35 $557-581$.

Forest Survey of India (FSI) 2013 Indian state of forest survey report; Dehradun.

Gilani H, Shrestha H L, Murthy M S R, Phuntso P, Pradhan S, Bajracharya B and Shrestha B 2015 Decadal land cover change dynamics in Bhutan; J. Environ. Manag. $14891-$ 100 .

Guangwei C 2002 Biodiversity in the eastern Himalayas: Conservation through dialogue; Summary reports of the workshops on biodiversity conservation in the Hindu Kush-Himalayan Ecoregion, ICIMOD, Kathmandu.

Gunderson L H 2000 Resilience in theory and practice; Ann. Rev. Ecol. Syst. 31 425-439.

Gunderson L H and Holling C S 2002 Panarchy: Understanding transformations in human and natural systems; Island Press, Washington DC, USA.

Hansen M C, Potapov P V, Moore R, Hancher M, Turubanova S A, Tyukavina A, Thau D, Stehman S V, Goetz S J, Loveland T R, Kommareddy A, Egorov A, Chini L, Justice C O and Townshend J R G 2013 Highresolution global maps of 21st-century forest cover change; Science 342 850-853.

Harris I P D J, Jones P D, Osborn T J and Lister D H 2014 Updated high-resolution grids of monthly climatic observations - the CRU TS3.10 Dataset; Int. J. Climatol. 34(3) 623-642.

Hirota M, Holmgren M, Nes E H and Scheffer M 2011 Global resilience of tropical forest and savanna to critical transitions; Science 334232.

Holling C S 1973 Resilience and stability of ecological systems; Ann. Rev. Ecol. Syst. 4 1-23.

Houghton R A 2005 Tropical deforestation as a source of greenhouse gas emissions; In: Tropical Deforestation and Climate Change (eds) Paulo Moutinho and Stephan Schwartzma, chapter 13.

Li Y, Sulla-Menashe D, Motesharrei S, Song X P, Kalnay E and Ying Q et al. 2017 Inconsistent estimates of forest cover change in China between 2000 and 2013 from multiple datasets: Differences in parameters, spatial resolution, and definitions; Sci. Rep-UK $\mathbf{7}$.

Maithani B P 2005 Shifting cultivation in north-east India: Policy issues and options; Mittal Publications.

Mon M S, Mizoue N, Htun N Z, Kajisa T and Yoshida S 2012 Factors affecting deforestation and forest 
degradation in selectively logged production forest: A case study in Myanmar; For. Ecol. Manag. 267 190-198.

Murthy M S R, Das P and Behera M D 2016 Road accessibility, population proximity and temperature increase are major drivers of forest cover change in the Hindu Kush Himalayan region; Curr. Sci. 111(10) 15991602.

Ning W, Rawat G S and Sharma E 2014 High-altitude ecosystem interfaces in the Hindu Kush Himalayan region. High-altitude rangelands and their interfaces in the Hindu Kush Himalayas; Vol. 3, ICIMOD, Kathmandu.

Panda R M, Behera M D, Roy P S and Biradar C 2017 Energy determines broad pattern of plant distribution in western Himalaya; Ecol. Evol. $\mathbf{7 ( 2 4 )}$ 10,850-10,860, https://doi.org/10.1002/ece3.3569.

Ramakrishnan P S 2007 Traditional forest knowledge and sustainable forestry: A north-east India perspective; For. Ecol. Manag. 249(1) 91-99.

Roy P S, Kushwaha S P S, Roy A, Murthy M S R, Singh S, Jha C S, Behera M D, Joshi P K, Jeganathan C, Karnatak C, Saran S, Reddy C S, Kushwaa D, Dutt C B S, Porwal M C, Sudhakar S and Srivastava V K 2013 Fragmentation in Indian forest; Curr. Sci. 105(6) 774-780.

Rudel T K, Coomes O T, Moran E, Achard F, Angelsen A, $\mathrm{Xu} \mathrm{J}$ and Lambin E 2005 Forest transitions: Towards a global understanding of land use change; Global Environ. Chang. 15(1) 23-31.

Saha R, Ghosh P K, Mishra V K, Majumdar B and Tomar J M S 2010 Can agroforestry be a resource conservation tool to maintain soil health in the fragile ecosystem of north-east India?; Outlook Agric. 39(3) 191-196.
Sharma E, Zhaoli Y and Sharma B 2007 ICIMOD's Regional Rangeland Program for the Hindu Kush-Himalayas; $M t$. Res. Dev. 27(2) 174-177.

Singh J S and Singh S P 1987 Forest vegetation of the Himalaya; Bot. Rev. 53(1) 80-192.

Songer M, Aung M, Senior B, DeFries R and Leimgruber P 2009 Spatial and temporal deforestation dynamics in protected and unprotected dry forests: A case study from Myanmar (Burma); Biodivers. Conserv. 18(4) 10011018.

Staver A C, Archibald S and Levin S A 2011 The global extent and determinants of savanna and forest as alternative biome states; Science 334230.

Tripathi P, Behera M D and Roy P S 2017 Optimized grid representation of plant species richness in India - Utility of an existing national database for integrated ecological analysis; PLoS ONE 12(3) e0173774.

Upadhyay T P, Sankhayan P L and Solberg B 2005 A review of carbon sequestration dynamics in the Himalayan region as a function of land-use change and forest/soil degradation with special reference to Nepal; Agr. Ecosyst. Environ. 105(3) 449-465.

Walker B H, Holling C S, Carpenter S R and Kinzig A S 2004 Resilience, adaptability and transformability; Ecol. Soc. $\mathbf{9}(\mathbf{2})$.

Zomer R J, Sharma E and Chettri N 2011 A need for mountain perspectives: Impacts of climate change on ecosystem services in the greater Hindu Kush-Himalayan region; In: Climate change: Global risks, challenges and decisions (eds) Richardson K, Steffen W and Liverman D, Cambridge University Press, Cambridge, pp. 110-112.

Corresponding editor: Prashant K SRIVAStava 